УДК 821.161.2.09 „18”

\section{Руслана СЛУХЕНСЬКА,}

ВДНЗ України „Буковинський державний медичний університет”, Чернівці (Україна)

\section{Ruslana SLUHENSKA}

Higher State Educational Establishment of Ukraine „Bukovinian State Medical University”, Chernivtsi (Ukraine), slyruslana@gmail.com

\section{ХЛОПЧИК ІЗ ГОЛУБОМ НА ПЛЕЧІ ДИТИНСТВО ТА ЮНІСТЬ ОСТАПА ВИШНІ}

\author{
THE BOY WITH THE DOVE ON HIS \\ SHOULDER: CHILDHOOD AND YOUTH \\ OF OSTAPVYSHNYA
}

\section{Ключевые слова: Остап Вишня, юмор, советская система, биография, детство, юность систела, биография, детство, юность. \\ Слухенская Руслана. Мальчик с голубем на плече: детство и юность Остапа Вишни. \\ Украинский юмор особый, он граничит с жанрами трагедии. Ярким примером трагикомедии есть жизнь и тво- рчество выдающегося, наиболее известного и уважаемого в народе украинского юмориста XX века Остапа Вишни. Ак- туальность статьи выражается тем, что постколониальное литературоведение и история литературы переживают вол- ну просмотров советского периода. Это открывает новый своеобразный дискурс литературы и писателей как ее соз- дателей, где поступки и тексты следует „считывать” между строк и действий.}

Український гумор особливий, він межує з жанрами трагедії. Яскравим прикладом трагікомедії $\epsilon$ життя та творчість найвидатнішого, найбільш знаного та шанованого в народі українського гумориста XX століття Остапа Вишні. Він був частиною народної душі, плекався нею та адресував усі свої твори народу як іiї невід'ємної константи. Справедливо буде сказати: творчість гумориста надихалась і окрилювалась великим поняттям "народ", про що він залишив свідчення у своїх записах: "Який би я був щасливий, - занотував письменник 15 травня 1949 р. в щоденнику, - якби своїми творами зміг викликати усмішку, хорошу, теплу усмішку у народу! Ви уявляєте собі: народ радісно усміхнувся! Але як це трудно!"1. Остап Вишня був вірним високому покликанню письменника, правді життя, любив і поважав людину. Це засвідчила його творчість, життєвий подвиг громадянина, якась гранична відкритість і зацікавленість гуманістичними проблемами. Його сміло можна назвати адвокатом народу, правозахисником без диплома.

Дитинство видатного українського письменника -гумориста Остапа Вишні припало на добу царизму, проте найбільших бід йому довелось скуштувати вже від радянської влади. Вимальовується в уяві такий собі веселий чоловік, душа компанії, що за словом в кишеню не полізе, сатиро-лірик, який обожнював полювання та відпочинок на природі, був чуйним і відкритим до людей. Хоч насправді доля одного з найвизначніших і найвідоміших українських гумористів дуже трагічна. $€$ особисті трагедії, а є трагедії, які творять режими, що руйнують цілі покоління, культурні епохи й народи. Його особиста трагедія спричинилася з трагедії цілого українського народу, що "встряг у московське болото".

Остапові Вишні "пощастило" родитись на зламі двох епох й отримати добрячого "прочухана" долі. Мимоволі напрошуються асоціації з назвою повісті
Генріха Бьоля "Очима клоуна" - він смішив всіх, видавався сильним та дуже дотепним, а за тим усім крилася тонка душа і зболена трагічна доля. Та про це мова йтиме пізніше. Спершу розглянемо дитинство та юнацькі роки письменника. Почнімо з екзистенційного зачину-ствердження автора в його ж біографiї: "У мене нема жодного сумніву в тому, що я народився, хоч і під час мого появлення на світ білий i потім - років, мабуть, із десять підряд - мати казали, що мене витягли з колодязя, коли напували корову Оришку”2. Тому і дослідник, і читач відразу розуміє, що матиме справу з "інтелектуальним" гумором.

Отож, Павло Губенко народився 13 листопада 1889 року на хуторі Чечва, що біля містечка Грунь Зіньківського повіту (нині село Грунь Охтирського району Сумської області) у маєтку поміщиків фон Рот. Незважаючи на те, що у різних нарисах про дату народження письменника говориться і про 11-те, 12те, 14-те листопада, та в автобіографії письменника чітко сказано про 1 листопада за старим стилем, тобто 13 листопада - за новим. "Хоч народився хлопчик у поміщицькому маєтку, але не належав він ні до дворянського, ні до поміщицького роду, і вперше його голос пролунав не у розкішних хоромах, а в селянській білій хаті"

Майбутній письменник був одним із 17 дітей бідної родини колишнього солдата царської армії Михайла Кіндратовича Губенка, який після звільнення $з$ армійських лав працював службовцем у панській управі фон Ротів. Батько майбутнього письменника довго ніс службу-муштру. У пошуках роботи опинився аж на хутірці з химерною назвою Чечва. Найнявся служити в маєток поміщиці-німкені фон Рот. Читаємо у спогадах: "Зустрів таку ж, як і сам, роботящу та дотепну на слово, дівчину - невдовзі Параска Олександрівна Балаш стала Михайловою дружиною. Обоє були письменними, любили жарт, щиро кохались у піснях. "А взагалі батьки були нічого собі лю- 
ди. Підходящі. За двадцять чотири роки спільного їхнього життя послав їм Господь усього тільки сімнадцятеро дітей, бо вміли вони молитись милосердному”. Про родовід Павла Губенка знаємо порівняно мало. У автобіографії 20-х років згадує: "Батьки мої були, як узагалі батьки. Батьків батько був у Лебедині шевцем. Материн батько був у Груні хліборобом. Глибшої генеалогії не довелося мені прослідити. Батько взагалі не дуже любив про родичів розказувати, а коли, було, спитаєш у баби (батькової матері) про діда чи там про прадіда, вона завжди казала:

- Отаке стерво було, як і ти оце! Покою від їх не було. Про материну рідню так само знаю небагато.

Тільки те й пам'ятаю, що частенько, було, батько казав матері:

- Не вдалася ти, голубонько, у свою матір. Царство небесне покійниці: і любила випити, і вміла випити".

Як відомо, людина без спогадів - людина без минулого. Саме від того, яким $\epsilon$ незабутній світ дитинства, залежить наше сприйняття тих чи інших явищ, людей, предметів. Письменником, якщо вірити оповідачеві автобіографічних творів, він став тому, що кваліфікації особливої не мав, бухгалтерії не знав, то й зробився Остапом Вишнею і почав писати. Факти біографії письменника щедро пересипані усмішками та гумором. На формування його особистості, наприклад, впливали такі інтелектуальні заняття, як-от: копання ямочок біля картоплі, толочення ногами панської клумби, лазання на бантину драти горобців або на вербу ганяти галченят. Отже, проходило шевченківсько-довженківське "золоте дитинство між природою і людьми". Аналізуючи свій розвиток та зростання, Остап Вишня "геніально" жартує у вже згадуваній автобіографії й каже: "Умови для мого розвитку були підходящі. 3 одного боку - колиска з вервечками, 3 другого боку - материні груди. Трішки поссеш, трішки поспиш - і ростеш собі помаленьку"5.

Уже в ранні роки Павло Губенко відзначався веселістю й великою тягою до читання. Рідна сестра письменника, заслужена вчителька Катерина Михайлівна Доценко, пригадувала: "Нас усіх дивувало, що Павлуша так рано навчився читати, а ще більше вражало те, що він не розлучався 3 книгою. 3 книгою його можна було побачити на ганку, на піддашках, 3 книжкою під пахвою я часто бачила його серед хлопчаків-товаришів, з якими він і в ліс ходив, i на річку, i в поле".

Найбільше любив читати письменник твори Миколи Гоголя ("Так от 3 дитинства і до старості з Гоголем" - писав у останні роки свого життя $)^{7}$. Федір Маківчук $з$ цього приводу пише: "Можу засвідчити, що то було сказано не для красного слівця (Вишня ніколи не вмів "рисуватися"), що це була сама правда, Гоголь жив у душі й серці Вишні. Вишня знав твори Гоголя, мабуть, краще, ніж свої власні. Певне, якби не Микола Васильович, - признавався Остап Вишня, то лікарював би я, очевидячки, всеньке своє життя, це він потяг мене в літературу"

3 тонкістю Остап Вишня "іронізує" над стереотипами в історії літератури та особливостями сприйняття персоналій письменників. Свідомий того, що жанр автобіографії видатної людини "вимагає" деталей формування особистості митця змалечку, гуморист жартує, ніби натякаючи, що ріс він абсолютно нормальним, енергійним життям жвавої сільської дитини: "Письменник не так живе й не так росте, як проста собі людина. Що проста людина? Живе собі, поживе собі, помре собі. А письменник - ні. Про письменника подай, обов'язково подай, що впливало на його світогляд, що його оточувало, що організовувало його ще тоді, коли він лежав у матері на руках і плямкав губами, зовсім не думаючи про те, що колись доведеться писати свою автобіографію. А от тепер сиди й думай, що на тебе вплинуло, що ти на письменника вийшов, яка тебе лиха година в літературу потягла, коли ти почав замислюватися над тим, "куди дірка дівається, як бублик їдять" ", .

Особливу любов і пієтет гуморист плекав до природи, у лоні якої пройшло все його дитинство й частина юності. Він був істинною дитиною полів, лісів та всієї живності, що заселяє їх, проводив багато часу, граючись надворі, на галявинах та лазячи по деревах. Знову звернемось до спогадів сестри: "Дуже любив Павлуша природу і все живе в ній. Любив поле, ліс. Особливо любив голубів, і вони його любили. Сидить, бувало, на ганку і читає, а на плечі у нього сидить його любимий голуб. 3 голубом на плечі можна його було побачити 3 хлопцями на прогулянках. Досить було Павлуші свиснути - голуб летів до нього i сідав на плече. Мама наша часто говорила: "Виросте $з$ Павла добра, хороша людина, бо його птиця любить",

Міркуючи над питаннями мистецького "фундаменту", Остап Вишня продовжує іронізувати й вимальовувати картину сільського життя "веселої" української родини, що тягне свій поведінковий "родовід" від "Кайдашевої сім'ї” Нечуя-Левицького до "Зачарованої Десни" Олесандра Довженка. І в уяві вимальовується дорослий чоловік, якому потрібно написати автобіографію, і він поступово занурюється, ретроспектує у глибокі спогади важкого, але такого милого дитинства. На його обличчі мимоволі проступає тепла посмішка від подібних картин з минулого. Так, читаємо зокрема таке: "Головну роль у формації майбутнього письменника відіграє взагалі природа - картопля, коноплі, бур'яни. Коли є в хлопчика чи в дівчинки нахил до замислювання, а навкруги росте картопля чи бур'ян, чи коноплі - амба! То вже так i знайте, що на письменника воно піде. I це цілком зрозуміло. Коли дитина замислиться й сяде на голому місці, хіба їй дадуть, як слід подумати? Зразу ж мати пужне:

- А де ж ти - ото сів, сукин ти, сину?

I натхнення 3 переляку розвіялось. Тут і стає в пригоді картопля. Так було й зо мною. За хатою недалеко - картопля, на підметі - коноплі. Сядеш собі: вітер віє, сонце гріє, картоплиння навіває думки. I все думаєш, думаєш, думаєш... Аж поки мати не крикне:

- Піди, подивися, Мелашко, чи не заснув там часом Павло? Та обережненько, не налякай, щоб сорочки не закаляв. Хіба на них наперешся?!"11 .

В автобіографії, що була написана у 20 -х роках читаємо: "Оддали мене у школу рано. Не було, мабуть, мені і шести літ. Скінчив школу, прийшов до- 
дому, а батько і каже: "Мало ти ще вчився. Треба ще куди оддавати. Повезу ще у Зіньків, повчись іще там, побачимо, що з тебе вийде". Повіз батько мене в 3іньків, хоч і тяжко йому було тоді, бо вже нас було шестеро чи семеро, а заробляв він не дуже. Проте повіз і віддав мене у Зіньківську міську двокласну школу. Зіньківську школу я закінчив року 1903 зі свідоцтвом, що маю право бути поштово-телеграфним чиновником - дуже якогось високого (чотирнадцятого, чи що) розряду. Та куди ж мені в ті чиновники, коли мені "тринадцятий минало". Поїхав додому. "Рано ти, - каже батько, закінчив науку. Куди ж тебе. Коли ти ще малий. Доведеться ще вчить, а в мене без тебе вже дванадцятеро". Та й повезла мене мати аж у Київ, у військово-фельдшерську школу, бо батько, як колишній солдат, мав право у ту школу дітей оддавати на "казьонний кошт"12.

Як бачимо, найбільше фактів та епізодів із життя письменника цього періоду ми можемо взяти з автобіографії. "Моя автобіографія" Остапа Вишні твір багатогранний. 3 одного боку подається ординарна біографічна інформація, наче відповідь на запитання анкети: дата народження, навчання, входження в літературу. А з іншого - розкривається образ ліричного героя - простака, який дотепно, 3 народним колоритом, розповідає про себе. Перед читачем постає дотепний, сповнений здорового глузду й самоіронії письменник - людина, яка готова перша посміятися iз себе. Саме гумор, "живий" сміх можна вважати ознакою внутрішньої свободи людини. Безумовно, Остап Вишня володів цим даром, бо в душі у нього завжди жив питомо народний сміх, який допоміг йому стати справжнім українським письменником.

Закінчивши у 1903 році Зіньківське повітове двокласне училище, він вступає на "казенне" навчання до Київської військово-фельдшерської школи як дитина колишнього солдата царської армії. Павло хотів вступити до Глухівської вчительської семінарії, але для цього потрібні були кошти. Тому мати відвезла хлопчика до Києва, де у військово-фельдшерській школі вже навчався старший брат Василь (згодом відомий український сатирик Василь Чечвянський). По закінченню навчання у 1907 році військовий фельдшер Павло Губенко потрапив до армії, а згодом працював у хірургічному відділенні лікарні Південно -Західних залізниць. Звідти Павло писав додому такі листи, що з них уся родина сміялася. Своїм сміхом він завжди підбадьорював і хворих, і медперсонал, оскільки після навчання працював до 1917-го у Київській залізничній лікарні.

Зрозумівши, що може смішно не тільки розповідати, а ще й написати, Вишня склав іспити на атестат зрілості та вступив до Київського університету. Та незабаром почалися криваві визвольні змагання за незалежність України, і навчатися вже стало неможливо. Згодом Остап Вишня написав так: "Як ударила революція - завертівся. Будував Україну. Де говорять - там і я. Державний муж, одне слово""13.

Для формування і становлення письменницького таланту Остапа Вишні велике значення мали певні біографічні чинники. Дитинство гумориста, як уже згадувалося, пройшло на Полтавщині, де особливо відчувались любов і шана до славетних земляків- класиків І.П. Котляревського й М.В. Гоголя; змалечку пізнавав Павло Губенко всі премудрості селянського буття, на власні очі бачив яскраві типи людей 3 українського колоритного села, захоплювався їхньою соковитою мовою, в якій озивалася дотепність народного гумору.

Остап Вишня - письменник, який у 20-х рр. заохотив мільйонні маси до читання української літератури. Він був "королем українського тиражу". За життя гумориста побачило світ понад 100 збірок його творів, деякі неодноразово перевидавалися. У великому творчому доробку письменника представлені різноманітні жанри малої прози (усмішка, гумореска, фейлетон, памфлет, автобіографічне оповідання), але скрізь присутній іронічно - усміхнений автор у ролі мудрого, дотепного оповідача.

Стаття зібрала в собі найважливіші факти та спогади про життя Остапа Вишні. Ми діахронічно розглянули всі життєві події автора, його творче зростання й професійну діяльність. Остап Вишня був активним газетярем, працював над розроблянням широкого радянського медіуму за інтересами. і його творчість була частиною цього медіуму - почасти викривального, почасти завуальованого, 3 гострим народним гумором та неперевершеною яскравою на метафори, свіжі порівняння, мовою. Він знав, як говорить народ, він вмів говорити його голосом, промовляти необхідні й бажані слова для простого люду. Саме це, під хвилю українізації в 20 -х роках, винесло автора на гребінь слави, але саме це вміння й знання не сподобалось радянській владі й письменникові довелось відбувати смертоносну "дясятирічку". Зрештою, саме це і робить його творчість невмирущою, актуальною, завжди "в темі", а його особу цікавою для дослідження й нового прочитання.

\section{References:}

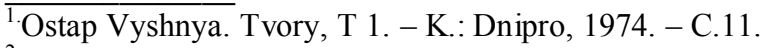

${ }^{2}$ Rozstrilyane vidrodzhennya: Antolohiya 1917 - 1933 : Poeziya - proza - drama - esey / uporyadkuv., peredym., pislyamova Yu. Lavrinenko; Pislyamova Yevhena Sverstuyuka. - K.: Smoloskyp, 2004. - S. 623.

${ }^{3}$ Fedir Makivchuk. Nevmyrushchyy (peredmova) // Ostap Vyshnya. Tvory, T 1. - K.: Dnipro, 1974. - C. 3.

${ }^{4}$.Rozstrilyane vidrodzhennya: Antolohiya 1917 - 1933 : Poeziya - proza - drama - esey / uporyadkuv., peredym., pislyamova Yu. Lavrinenko; Pislyamova Yevhena Sverstuyuka. - K.: Smoloskyp, 2004. - S. 626.

${ }^{5}$ Rozstrilyane vidrodzhennya: Antolohiya 1917 - 1933 : Poeziya - proza - drama - esey / uporyadkuv., peredym., pislyamova Yu. Lavrinenko; Pislyamova Yevhena Sverstuyuka. - K.: Smoloskyp, 2004. - S. 623.

${ }^{6}$ Fedir Makivchuk. Nevmyrushchyy (peredmova) // Ostap Vyshnya. Tvory, T 1. - K.: Dnipro, 1974. - C.4.

${ }^{7}$ Ibid, S. 4.

${ }^{8}$ Ostap Vyshnya. Tvory, T 1. - K.: Dnipro, 1974. - S. 5.

${ }^{9}$ Rozstrilyane vidrodzhennya: Antolohiya 1917 - 1933 : Poeziya - proza - drama - esey / uporyadkuv., peredym., pislyamova Yu. Lavrinenko; Pislyamova Yevhena Sverstuyuka. - K.: Smoloskyp, 2004. - S. 626.

${ }^{10}$ Fedir Makivchuk. Nevmyrushchyy (peredmova) // Ostap Vyshnya. Tvory, T 1. - K.: Dnipro, 1974. - S 4.

${ }^{11}$ Rozstrilyane vidrodzhennya: Antolohiya 1917 - 1933 : 
Poeziya - proza - drama - esey / uporyadkuv., peredym., pislyamova Yu. Lavrinenko; Pislyamova Yevhena Sverstuyuka. - K.: Smoloskyp, 2004. - S. 626.

12. Ostap Vyshnya. Tvory, T 1. - K.: Dnipro, 1974. - S 3-4.

${ }^{13 .}$ Rozstrilyane vidrodzhennya: Antolohiya 1917 - 1933 : Poeziya - proza - drama - esey / uporyadkuv., peredym., pislyamova Yu. Lavrinenko; Pislyamova Yevhena Sverstuyuka. - K.: Smoloskyp, 2004. - S. 631.

Sluhenska Ruslana. The boy with the dove on his shoulder: childhood and youth of OstapVyshnya. Ukrainian humor is a particular genre, it resembles tragedy. A striking example of the tragicomedy is life and work of OstapVyshnya - the most outstanding, and the most famous Ukrainian humorist of the XX century respected by the people.

The importance of the article is reflected in the hit wave of revision and reinterpretation of the post-colonial Soviet literary criticism, literary history, and the literature. This opens a new kind of discourse of literature full of suggestions and writers as its creators, where the works and texts should be „read" between lines and actions, where the surviving artists attempted to squeeze through the „heavy artillery shelling” of the Soviet system. They were writing a lot, they were writing on various subjects, they were creating the myth of the system. That is the myth that modern scholars should decode, the „myth as a school of the survival".

The objective of the research is to rethink the writer as a person, in a linear viewing of his biography, not separating the „communist" from the "Ukrainian” period, as despite the "complete rehabilitation" and attempt to "curry favor" in the late 40 s - early 50 s, Vyshnya , jailed" on in full measure in exile. Childhood of the famous Ukrainian writer-humorist OstapVyshnya occurred in the the tsarist days, but he was the subject to the biggest troubles from the Soviet authorities. There are personal tragedies, but there are tragedies that create regimes destroying entire generations, cultural epochs and nations. His personal tragedy was stipulated by the tragedy of the Ukrainian nation that turned into ,the Moscow swamp".

OstapVyshnya was true to a high calling of the writer, the truth of life, he had love and respect for mankind. It was reflected in his work, fulfilled civic duties, some marginal transparency and interest in humanistic problems. He can easily be called the advocate for a people, the human rights devoted without a degree. He was part of the folk spirit, was empowered by it and devoted all his works to the people as his inseparable constant. It's fair to say that creativity of OstapVyshnya was inspired by the great concept of ,nation”, as he left the evidence about this in his diaries.

Key words: OstapVyshnya, humor, Soviet system, biography, childhood, youth.

Sluhenska Ruslana - Candidate of pedagogical sciences, lecturer of the Department of internal medicine, physical rehabilitation and sports medicine Higher Educational Establishment of Ukraine „Bukovinian State Medical University”. Scientific interests of the author are the following: pedagogy of higher education, philology. The scientist is the author of over 20 scientific articles.

Слухенська Руслана - кандидат педагогічних наук, викладач кафедри внутрішньої медичини, фізичної реабілітаиії та спортивної медицини Вищого державного навчального закладу Украӥни „Буковинський державний медичний університет”. Коло наукових інтересів: педагогіка вищої школи, філологія. Автор більше 20 наукових статей.

Received: 05-11-2016

Advance Acces Publischer: December 2016

(C) R. Sluhenska, 2016 